\title{
PEMODELAN JUMLAH KASUS COVID-19 DI INDONESIA DENGAN PENDEKATAN REGRESI POISSON DAN REGRESI BINOMIAL NEGATIF
}

\author{
Studi Kasus 34 Provinsi di Indonesia \\ (Modelling The Number Of COVID-19 Cases In Indonesia Using Poisson Regression And \\ Binomial Regression Approach )
}

\author{
Nadhifan Humam Fitrial ${ }^{1}$, Akhmad Fatikhurrizqi ${ }^{2}$ \\ ${ }^{1}$ Politeknik Statistika STIS \\ ${ }^{2}$ Politeknik Statistika STIS \\ Jalan Otto Iskanardinata No.64C, Kota Jakarta Timur, DKI Jakarta 1330 \\ E-mail: 211709877@stis.ac.id
}

\begin{abstract}
ABSTRAK
Pandemi COVID-19 telah merebak di seluruh penjuru dunia, termasuk Indonesia. Perlu diketahui berbagai faktor yang memengaruhi tersebarnya kasus COVID-19 di suatu wilayah sehingga baik pemerintah maupun masyarakat dapat melakukan upaya pencegahan dan penanggulanan agar pandemi ini tidak semakin menyebar. Penelitian ini bertujuan memodelkan jumlah kasus COVID-19 di Indonesia kemudian menentukan variabel-variabel yang berpengaruh signifikan terhadapnya. Model yang digunakan adalah regresi Poisson dan regresi Binomial Negatif. Kedua model dipilih karena merupakan model yang sering digunakan terhadap data cacah seperti jumlah kasus COVID-19. Kemudian dari kedua model akan dipilih model terbaik beserta variabel yang berpengaruh signifikan terhadap jumlah kasus COVID-19 di Indonesia. Unit analisis dalam penelitian ini adalah seluruh wilayah provinsi di Indonesia yang terdiri atas 34 provinsi. Variabel respon dalam penelitian ini adalah jumlah kasus kumulatif COVID-19 di Indonesia pada tanggal 9 April 2020 yang dihimpun dari Gugus Tugas Percepatan Penanganan COVID-19. Tanggal tersebut dipilih karena merupakan tanggal sebelum diberlakukannya kebijakan PSBB yang pertama kali di Indonesia dan penelitian ini tidak mengambil variabel intervensi pemerintah dalam memodelkan jumlah kumulatif COVID19. Adapun variabel prediktor dalam penelitian ini adalah kepadatan penduduk, persentase penduduk lansia, persentase ruta dengan akses sanitasi tidak layak, dan persentase angka buta huruf penduduk usia 15 tahun keatas. Berdasarkan nilai AIC, regresi Binomial Negatif lebih baik digunakan untuk memodelkan jumlah kasus COVID-19 di Indonesia dibandingkan regresi Poisson.Pada model regresi Binomial Negatif, variabel kepadatan penduduk dan persentase penduduk lansia berpengaruh positif dan signifikan terhadap jumlah kasus COVID-19 di Indonesia.
\end{abstract}

Kata kunci: COVID-19, regresi poisson, regresi binomial negatif

\begin{abstract}
The COVID-19 pandemic has spread throughout the world, including Indonesia. It is necessary to know the various factors that affect the spread of COVID-19 cases so that both the government and the community can make prevention and response efforts so that this pandemic does not spread further. This study aims to model the number of COVID-19 cases in Indonesia and then determine the variables that have a significant effect on them. The model used is Poisson regression and Negative Binomial regression. The two models were chosen because they are a model that is often used for count data such as the number of COVID-19 cases. Then from the two models, the best model will be selected along with the variables that have a significant effect on the number of COVID-19 cases in Indonesia. The unit of analysis in this research is all provinces in Indonesia which consists of 34 provinces. The response variable in this study is the cumulative number of COVID-19 cases in Indonesia on April 9, 2020 which were compiled from Gugus Tugas Percepatan Penanganan COVID-19. This date was chosen because it was the date before the implementation of the PSBB policy for the first time in Indonesia and this study did not take government intervention variables in modeling the cumulative number of COVID-19. The predictor variables in this study were population density, the percentage of the elderly population, the percentage of households with access to improper sanitation, and the percentage of illiteracy rates for the population aged 15 years and over. Based on the AIC value, the Negative Binomial regression is better used to model the number of COVID-19 cases in Indonesia than the Poisson regression. In the Negative Binomial regression model, the population
\end{abstract}


density variable and the percentage of the elderly population have a positive and significant effect on the number of COVID-19 cases in Indonesia.

Keywords: COVID-19, poisson regression, negative binomial regression

\section{PENDAHULUAN}

Kementerian Kesehatan Indonesia menyatakan bahwa Coronavirus merupakan keluarga besar virus yang menyebabkan penyakit pada manusia dan hewan. Pada manusia biasanya menyebabkan penyakit infeksi saluran pernapasan, mulai flu biasa hingga penyakit yang serius seperti Middle East Respiratory Syndrome (MERS) dan Sindrom Pernafasan Akut Berat/Severe Acute Respiratory Syndrome (SARS). Coronavirus jenis baru yang ditemukan pada manusia sejak kejadian luar biasa muncul di Wuhan Cina, pada Desember 2019, kemudian diberi nama Severe Acute Respiratory Syndrome Coronavirus 2 (SARS-COV2), dan menyebabkan penyakit Coronavirus Disease-2019 (COVID-19). Virus jenis baru tersebut bahkan menyebabkan status pandemi, yang berarti penyebaran virus terjadi dalam wilayah geografis yang luas hingga seluruh penjuru dunia, termasuk Indonesia. Persebaran virus ini dapat dikatakan sangat cepat hingga dalam kurun lima bulan kasus positif COVID-19 di Indonesia menembus 100.000 kasus. Hingga September 2020, kasus COVID-19 di Indonesia terus meningkat dan tak satu provinsi pun luput dari paparan pandemi ini. Berikut grafik kasus harian pasien COVID-19 di Indonesia.

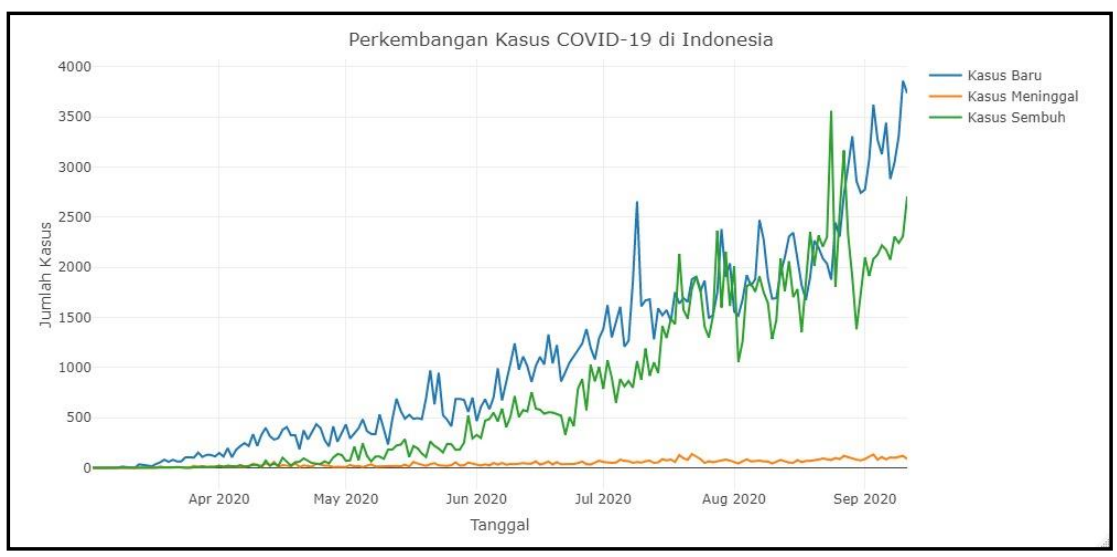

Sumber: Gugus Tugas Percepatan Penanganan COVID-19 Indonesia

Gambar 1. Perkembangan Kasus COVID-19 di Indonesia

Gambar 1 menunjukkan bahwa penambahan kasus baru COVID-19 di Indonesia cenderung terus meningkat. Per 11 September 2020 terdapat 3.737 peningkatan kasus baru dengan jumlah kumulatif sejak 2 Maret 2020 mencapai 210.940 kasus yang tersebar di 34 provinsi di Indonesia. Salah satu penyebab cepatnya persebaran virus tersebut yaitu terdapat orang yang terkonfirmasi positif, namun tidak menunjukkan gejala apapun. Bahkan hanya sekitar satu dari enam orang yang terkonfirmasi positif COVID-19 akan menderita sakit parah, seperti disertai pneumonia atau kesulitan nafas. Namun, hal ini menjadi sangat rentan terhadap orang lanjut usia dan orang-orang yang sudah memiliki kondisi medis, seperti diabetes, tekanan darah tinggi, dan penyakit jantung (Kementerian Kesehatan Indonesia). Oleh karena itu, persebaran virus tersebut harus segera diminimalisasi dengan penanganan yang maksimal sejak kasus terkonfirmasi positif di awal.

Berdasarkan penjelasan tersebut, perlu diketahui berbagai faktor yang memengaruhi tersebarnya kasus COVID-19 di suatu wilayah sehingga baik pemerintah maupun masyarakat dapat melakukan upaya pencegahan dan penanggulanan agar pandemi ini tidak semakin menyebar. Terdapat berbagai studi mengenai berbagai faktor yang berpengaruh terhadap tersebarnya suatu pandemi atau virus penyakit. Wilayah yang padat penduduk cenderung memiliki mobilitas yang tinggi sehingga rentan terhadap persebaran berbagai penyakit (Moore et al., 2016). Kemudian penduduk yang berusia tua lebih rentan terkena virus dan penyakit menular dan jika 
sudah terkena, mereka memiliki resiko kematian yang tinggi (Peeri et al., 2020). Selain itu, penduduk yang memiliki tingkat pendidikan yang baik akan lebih terdidik dalam mentaati aturan pencegahan serta lebih memahami tentang penyakit sehingga dapat lebih melindungi dirinya dari penyakit (KC dan Lentzner, 2010). Belum ditemukannya vaksin untuk menangkal COVID-19, akses terhadap sanitasi yang layak diharapkan menjadi pertahanan pertama dalam menangkal tersebarnya virus penyakit (WHO, 2020).

Penelitian ini bertujuan menentukan model yang dapat menggambarkan jumlah kasus COVID-19 di Indonesia dengan baik. Model yang digunakan adalah regresi Poisson dan regresi Binomial Negatif. Kedua model dipilih karena merupakan model yang sering digunakan terhadap data cacah seperti jumlah kasus COVID-19. Kemudian berdasarkan model terbaik akan ditentukan variabel yang berpengaruh signifikan terhadap jumlah kasus COVID-19 di Indonesia.

\section{METODE}

\subsection{Kajian Teori \\ Regresi Poisson}

Salah satu model yang sering digunakan untuk memodelkan variabel respon berupa data cacah adalah regresi Poisson. Regresi Poisson didasarkan kepada karakteristik dan penggunaan dari distribusi Poisson. Distribusi Poisson adalah distribusi suatu variabel acak yang dinyatakan banyaknya hasil percobaan yang terjadi dalam suatu selang waktu tertentu atau di wilayah tertentu. Fungsi kepadatan peluang dari distribusi Poisson adalah sebagai berikut:

$$
P(Y=y)=\frac{\mu^{y} \exp (\mu)}{y_{i} !}
$$

Dengan $\mu$ merupakan parameter rata-rata dari variabel acak $y$ yang diasumsikan sama untuk semua kejadian $y$ Kemudian itu distribusi Poisson mengasumsikan bahwa nilai $\mu$ dari variabel acak $y$ mempunyai nilai yang sama dengan variansnya.

Regresi Poisson termasuk ke dalam keluarga Generalized Linear Models (GLM) yang merupakan perluasan dari model regresi klasik. Pada regresi Poisson fungsi hubung yang digunakan adalah logaritma natural sehingga menghasilkan hubungan yang log-linear antara variabel respon dengan variabel prediktor. Sehingga model yang dihasilkan memiliki persamaan sebagai berikut:

$\mu_{i}=\exp \left(\beta_{0}+\sum_{j=1}^{k} \beta_{1 j} X_{i j}\right)$

Penaksiran parameter pada model regresi Poisson dilakukan dengan menggunakan maximum likelihood estimation (MLE). Adapun fungsi likelihood yang akan dimaksimalkan dalam regresi Poisson adalah sebagai berikut :

$$
\ln L\left(\beta, y_{i}\right)=\sum_{i=1}^{n}\left[y_{i}\left(x_{i}^{T} \boldsymbol{\beta}\right)-\exp \left(x_{i}^{T} \boldsymbol{\beta}\right)-\right.
$$

$\left.\ln \left(y_{i} !\right)\right]$......

Namun, penyelesaian dengan cara tersebut terkadang tidak menghasilkan hasil yang eksplisit (fungsi MLE tidak converge) sehingga alternatif lain untuk mendapatkan penyelesaiannya adalah dengan metode iterasi numerik Newton-Rapson.

\section{Overdispersi}

Salah satu asumsi yang harus dipenuhi ketika memodelkan regresi Poisson adalah nilai ratarata variabel respon memiliki nilai yang sama dengan variansnya atau biasa dikenal dengan equidispersi. Namun, dalam prakteknya sering didapati variabel yang berupa data cacah memiliki nilai varians yang lebih besar dibanding dengan nilai rata-ratanya. Kondisi ini biasa dikenal dengan overdispersi. Masalah overdispersi dapat menyebabkan nilai estimasi parameter yang bias dan tidak dapat menangkap fenomena yang sesungguhnya. Salah satu indikasi ada atau tidaknya overdispersi dapat diketahui melalui pembagian antara nilai deviance dengan derajat bebasnya. Apabila nilainya lebih dari 1 , hal ini mengindikasikan adanya overdispersi. 


\section{Regresi Binomial Negatif}

Salah satu metode yang dapat mengatasi overdispersi pada regresi Poisson adalah metode regresi Binomial Negatif yang didasarkan pada model gabungan Poisson-Gamma (Zeileis et al., 2008). Fungsi kepadatan peluang dari distribusi Binomial Negatif adalah:

$f(y ; \mu, \theta)=\frac{\Gamma(y+\theta)}{\Gamma(\theta) y !} \frac{\mu^{y} \theta^{\theta}}{(\mu+\theta)^{y+\theta}}$.

dengan parameter rata-rata $\mu$ dan parameter dispersi $\theta$ dengan $\Gamma($.$) merupakan fungsi gamma.$ Seperti regresi Poisson, regresi Binomial Negatif juga termasuk ke dalam keluarga Generalized Linear Models (GLM) dan memiliki fungsi hubung berupa logaritma natural sehingga menghasilkan hubungan yang log-linear antara variabel respon dengan variabel prediktor. Sehingga model yang dihasilkan memiliki persamaan sebagai berikut:

$\mu_{i}=\exp \left(\beta_{0}+\sum_{j=1}^{k} \beta_{1 j} X_{i j}\right)$

Penaksiran parameter pada model regresi Binomial Negatif dilakukan dengan menggunakan maximum likelihood estimation (MLE). Adapun fungsi likelihood yang akan dimaksimalkan dalam regresi Binomial Negatif adalah sebagai berikut :

$\ln L\left(\beta, y_{i}, \theta\right)=\sum_{i=1}^{n}\left\{y_{i} \ln \left(\frac{\theta \exp \left(x_{i}^{T} \boldsymbol{\beta}\right)}{1+\theta \exp \left(x_{i}^{T} \boldsymbol{\beta}\right)}\right)-\left(\frac{1}{\theta}\right) \ln \left(1+\theta \exp \left(x_{i}^{T} \boldsymbol{\beta}\right)\right)+\ln \Gamma\left(y_{i}+\frac{1}{\theta}\right)-\ln \Gamma\left(y_{i}+1\right)-\right.$ $\left.\ln \Gamma\left(\frac{1}{\theta}\right)\right\}$

Namun, penyelesaian dengan cara tersebut terkadang tidak menghasilkan hasil yang eksplisit (fungsi MLE tidak converge) sehingga alternatif lain untuk mendapatkan penyelesaiannya adalah dengan metode iterasi numerik Newton-Rapson.

\section{Pengujian Parameter Regresi Poisson dan Regresi Binomial Negatif}

Pengujian parameter dilakukan untuk mengetahui pengaruh variabel prediktor terhadap variabel respon.Pengujian parameter dilakukan secara simultan dan parsial. Baik regresi Poisson maupun regresi Binomial Negatif memiliki metode yang sama dalam pengujian parameter secara simultan maupun secara parsial.

Pengujian simultan bertujuan untuk mengetahui pengaruh serentak/bersama-sama variabel prediktor terhadap variabel respon. Hipotesis dari pengujian simultan yang digunakan adalah:

$H_{0}: \beta_{1}=\beta_{2}=\cdots=\beta_{k}=0$

$H_{1}$ : minimal terdapat satu $\beta_{j}=0$, untuk setiap $\mathrm{j}=1,2, \ldots, \mathrm{k}$

Statistik uji yang digunakan adalah:

$G=-2 \ln \left(\frac{L(\widehat{\omega})}{L(\widehat{\Omega})}\right)$

dengan $L(\widehat{\omega})$ merupakan besar likelihood untuk himpunan parameter di bawah $\mathrm{H}_{0}$ (intercept only) sementara $L(\widehat{\Omega})$ merupakan besar likelihood ketika memasukkan seluruh variabel prediktor. Hipotesis nol ditolak jika nilai $G>\chi_{(\alpha, k)}^{2}$ dengan $\alpha$ merupakan tingkat signifikansi tertentu dan $\mathrm{k}$ adalah jumlah parameter.

Adapun pengujian parameter secara parsial bertujuan untuk mengetahui pengaruh masingmasing variabel prediktor terhadap variabel respon. Hipotesis dari pengujian simultan yang digunakan adalah:

$H_{0}: \beta_{j}=0$

$H_{1}: \beta_{j} \neq 0$, untuk setiap $\mathrm{j}=1,2, \ldots, \mathrm{k}$

Statistik uji yang digunakan adalah:

$Z=\frac{\widehat{\beta_{J}}}{\operatorname{se}\left(\widehat{\beta}_{j}\right)}$

Hipotesis nol ditolak jika nilai $Z>Z_{\alpha / 2}$ dengan $\alpha$ merupakan tingkat signifikansi tertentu.

\section{Evaluasi Hasil Model}

Evaluasi model dilakukan dengan cara membandingkan nilai Akaike Information Criterion (AIC). Model terbaik yang dipilih adalah model yang memiliki nilai AIC terkecil. Gill (2001) menuliskan formula penghitungan AIC sebagai berikut: 
$A I C=-2 l(\hat{\theta} \mid y)+2 p$

dengan $l(\hat{\theta} \mid y)$ merupakan nilai maksimum log-likelihood dan $\mathrm{p}$ adalah banyaknya parameter.

\subsection{Ruang Lingkup dan Sumber Data}

Unit analisis dalam penelitian ini adalah seluruh wilayah provinsi di Indonesia yang terdiri atas 34 provinsi. Variabel respon dalam penelitian ini adalah jumlah kasus kumulatif COVID-19 di Indonesia pada tanggal 9 April 2020 yang dihimpun dari Gugus Tugas Percepatan Penanganan COVID-19. Kasus COVID-19 didefinisikan sebagai seseorang yang sudah dinyatakan positif terinfeksi COVID-19 melalui uji PCR hasil pemeriksaan laboratorium. Adapun dipilihnya tanggal 9 April 2020 adalah karena waktu tersebut merupakan waktu sebelum diberlakukannya kebijakan PSBB yang pertama kali di Indonesia (kebijakan PSBB pertama kali tanggal 10 April 2020 di Provinsi DKI Jakarta) dan penelitian ini tidak mengambil variabel intervensi pemerintah dalam memodelkan jumlah kasus kumulatif COVID-19 di Indonesia. Adapun variabel prediktor dalam penelitian ini adalah kepadatan penduduk $\left(X_{1}\right)$, persentase penduduk lansia $\left(X_{2}\right)$, persentase rumah tangga dengan akses sanitasi tidak layak $\left(X_{3}\right)$, dan persentase angka buta huruf penduduk usia 15 tahun keatas $\left(\mathrm{X}_{4}\right)$. Data keempat variabel prediktor merupakan data pada tahun 2019 yang dihimpun dari Badan Pusat Statistik. Pada penelitian ini, data variabel prediktor diasumsikan tetap dan sama dengan data pada tahun 2020.

\subsection{Tahapan Analisis}

Tahapan analisis diawali dengan pengujian asumsi multikolinearitas. Selanjutnya pembuatan model regresi Poisson beserta memeriksa adanya overdispersi pada hasil regresi Poisson. Langkah selanjutnya adalah membuat model dengan menggunakan metode regresi Binomial. Langkah terakhir yaitu membandingkan hasil regresi Poisson dengan regresi Binomial Negatif dan memilih model terbaik dari kedua model tersebut berdasarkan nilai AIC yang terkecil.

\section{HASIL DAN PEMBAHASAN}

\subsection{Pengujian Asumsi Multikolinearitas}

Sebelum dilakukan pemodelan, dilakukan pemeriksaan multikolinearitas dengan menggunakan nilai Variance Inflation Factor (VIF). Hasil pemeriksaan menunjukkan bahwa tidak terdapat variabel yang memiliki nilai VIF lebih dari 10. Hal tersebut menunjukkan bahwasanya bahwa tidak terdapat korelasi antara variabel prediktor sehingga asumsi non-multikolinearitas terpenuhi dan keempat variabel prediktor dapat digunakan dalam pembentukan model.

Tabel 1. Nilai VIF

\begin{tabular}{cc}
\hline Variabel & VIF \\
\hline$X_{1}$ & 3,78 \\
$X_{2}$ & 1,85 \\
$X_{3}$ & 3,89 \\
$X_{4}$ & 1,78
\end{tabular}

Sumber: Output $R$

\subsection{Pemodelan Kasus COVID-19 di Indonesia dengan Regresi Poisson}

Pemodelan dengan regresi Poisson digunakan untuk memodelkan jumlah kasus kumulatif COVID-19 (hingga tanggal 9 April 2020) dengan variabel adalah kepadatan penduduk $\left(\mathrm{X}_{1}\right)$, persentase penduduk lansia $\left(\mathrm{X}_{2}\right)$, persentase rumah tangga dengan akses sanitasi tidak layak $\left(\mathrm{X}_{3}\right)$, dan persentase angka buta huruf penduduk usia 15 tahun keatas $\left(\mathrm{X}_{4}\right)$. Dengan bantuan perangkat $R$ hasil estimasi parameter yang didapat adalah sebagai berikut. 
Tabel 2. Hasil Estimasi Parameter Regresi Poisson

\begin{tabular}{cccc}
\hline Variabel & Estimasi $\beta$ & Standard Error $\beta$ & $p$-value \\
\hline Intercept & $7,82 \times 10^{-1}$ & $1,55 \times 10^{-1}$ & 0,000 \\
$\mathrm{X}_{1}$ & $2,83 \times 10^{-4}$ & $4,34 \times 10^{-6}$ & 0,00 \\
$\mathrm{X}_{2}$ & $2,44 \times 10^{-1}$ & $1,09 \times 10^{-2}$ & 0,00 \\
$\mathrm{X}_{3}$ & $-3,55 \times 10^{-2}$ & $3,20 \times 10^{-3}$ & 0,00 \\
$\mathrm{X}_{4}$ & $-1,45 \times 10^{-3}$ & $6,58 \times 10^{-3}$ & 0,83
\end{tabular}

Sumber: Output $R$

Berdasarkan tabel diatas, persamaan regresi Poisson yang terbentuk adalah: $\mu=\exp \left(4,338+2,83 \times 10^{-4} X_{1}+2,44 \times 10^{-1} X_{2}-3,55 \times 10^{-2} X_{3}-1,45 \times 10^{-3} X_{4}\right)$

Hasil uji parsial menunjukkan dari empat variabel prediktor, terdapat tiga variabel yang berpengaruh signifikan terhadap jumlah kasus COVID-19 di Indonesia yaitu kepadatan penduduk, persentase penduduk lansia, dan persentase rumah tangga dengan akses sanitasi tidak layak. Berdasarkan nilai koefisiennya, variabel kepadatan penduduk dan persentase penduduk lansia berpengaruh positif terhadap jumlah kasus COVID-19 di Indonesia adapun variabel akses sanitasi tidak layak berpengaruh negatif terhadap jumlah kasus COVID-19 di Indonesia.

Pengujian selanjutnya adalah pengujian overdispersi. Hasil dari pengujian overdispersi menunjukkan menunjukkan bahwa terjadi overdispersi pada model regresi Poisson yang terbentuk yang ditunjukkan dari nilai rasio antara deviance dengan derajat bebasnya yang lebih dari 1.

Tabel 3. Pengujian Overdispersi

\begin{tabular}{ccc}
\hline Deviance & df & Deviance/df \\
\hline 2278.3 & 29 & 78,56 \\
Sumber: Output $R$ & &
\end{tabular}

\subsection{Pemodelan Kasus COVID-19 di Indonesia dengan Regresi Binomial Negatif}

Metode alternatif yang dapat digunakan untuk memodelkan data cacah yang mengalami overdispersi adalah regresi Binomial Negatif. Hasil estimasi parameter model regresi Binomial Negatif dengan bantuan perangkat $R$ diperoleh persamaan sebagai berikut:

Tabel 4. Hasil Estimasi Parameter Regresi Binomial Negatif

\begin{tabular}{cccc}
\hline Variabel & Estimasi $\beta$ & Standard Error $\beta$ & $p$-value \\
\hline Intercept & 1,50 & 1,16 & 0,20 \\
$\mathrm{X}_{1}$ & $4,02 \times 10^{-4}$ & $8,28 \times 10^{-5}$ & 0,00 \\
$\mathrm{X}_{2}$ & $2,01 \times 10^{-1}$ & $9,94 \times 10^{-2}$ & 0,04 \\
$\mathrm{X}_{3}$ & $5,70 \times 10^{-3}$ & $2,65 \times 10^{-2}$ & 0,83 \\
$\mathrm{X}_{4}$ & $3,68 \times 10^{-2}$ & $5,68 \times 10^{-2}$ & 0,52
\end{tabular}

Sumber: Output $R$

Berdasarkan tabel diatas, persamaan regresi Binomial Negatif yang terbentuk adalah: $\mu=\exp \left(1,5+4,02 \times 10^{-4} X_{1}+2,01 \times 10^{-1} X_{2}+5,70 \times 10^{-3} X_{3}+3,68 \times 10^{-2} X_{4}\right)$

Hasil uji parsial menunjukkan dari empat variabel prediktor, terdapat dua variabel yang berpengaruh signifikan terhadap jumlah kasus COVID-19 di Indonesia yaitu kepadatan penduduk dan persentase penduduk lansia. Berdasarkan nilai koefisiennya, variabel kepadatan penduduk dan persentase penduduk lansia berpengaruh positif terhadap jumlah kasus COVID-19 di Indonesia. 


\subsection{Pemilihan Model Terbaik}

Pemilihan model terbaik diantara regresi Poisson dengan regresi Binomial Negatif didasarkan pada nilai AIC. Model terbaik yang dipilih adalah model yang memiliki kriteria nilai AIC terkecil. Hasil nilai AIC kedua model regresi terlampir dalam tabel berikut.

Tabel 5. Nilai AIC

\begin{tabular}{cc}
\hline Model & AIC \\
\hline Regresi Poisson & 2444,9 \\
Regresi & 327,44 \\
$\begin{array}{c}\text { Binomial Negatif } \\
\text { Sumber: Output } R\end{array}$ &
\end{tabular}

Berdasarkan tabel diatas, model regresi Binomial Negatif lebih baik dalam memodelkan jumlah kasus COVID-19 di Indonesia dibanding model regresi Poisson. Hal ini didasarkan pada nilai AIC pada model regresi Binomial Negatif lebih kecil dibandingkan model regresi Poisson.

\section{KESIMPULAN}

Berdasarkan pembahasan yang telah dilakukan, dapat ditarik kesimpulan bahwa jumlah kasus kumulatif COVID-19 di Indonesia masih terus meningkat dan belum menampakkan gejala penurunan. Perlu diketahui informasi terkait variabel-variabel yang memengaruhi tersebarnya kasus COVID-19 di Indonesia sehingga baik pemerintah maupun masyarakat dapat melakukan upaya pencegahan dan penanggulanan agar pandemi ini tidak semakin menyebar. Model yang digunakan adalah regresi Poisson dan regresi Binomial Negatif. Kedua model dipilih karena merupakan model yang sering digunakan terhadap data cacah seperti jumlah kasus COVID-19. Berdasarkan nilai AIC, regresi Binomial Negatif lebih baik digunakan untuk memodelkan jumlah kasus COVID-19 di Indonesia dibandingkan regresi Poisson.Pada model regresi Binomial Negatif, variabel kepadatan penduduk dan persentase penduduk lansia berpengaruh positif dan signifikan terhadap jumlah kasus COVID-19 di Indonesia.

\section{DAFTAR PUSTAKA}

Moore, M., Gelfeld, B., Okunogbe, A., \& Christopher, P. (2016). Identifying future disease hot spots: infectious disease vulnerability index. Rand Corporation.

Peeri, N. C., Shrestha, N., Rahman, M. S., Zaki, R., Tan, Z., Bibi, S., Baghbanzadeh, M., Aghamohammadi, N., Zhang, W., \& Haque, U. (2020). The SARS, MERS and novel coronavirus (COVID-19) epidemics, the newest and biggest global health threats: what lessons have we learned?. International journal of epidemiology, 49(3), 717-726. https://doi.org/10.1093/ije/dyaa033

Kc, S., \& Lentzner, H. (2010). The effect of education on adult mortality and disability: a global perspective. Vienna Yearbook of Population Research, 201-235.

Zeileis, A., Kleiber, C., \& Jackman, S. (2008). Regression models for count data in R. Journal of statistical software, 27(8), 1-25.

World Health Organization. (2020). Water, sanitation, hygiene, and waste management for the COVID-19 virus: interim guidance, 23 April 2020 (No. WHO/2019-nCoV/IPC_WASH/2020.3). World Health Organization 
Safitri, Aulia, dkk. (2009). Penerapan Regresi Poisson dan Binomial Negatif dalam Memodelkan Jumlah Kasus Penderita AIDS di Indonesia Berdasarkan Faktor Sosiodemografi. Jurnal Matematika UNAND Vol.3 No 4, 17(5), 639-658.

Oztig, Lacin \& Askin, Oykum. (2020). Human Mobility and COVID-19: A Negative Binomial Regression Analysis. Public Health. 185. 10.1016/j.puhe.2020.07.002. 